\title{
Universiteit
}

Leiden

The Netherlands

\section{The stages of new political regimes: the transformation of} capital cities

Blockmans, W.P.

\section{Citation}

Blockmans, W. P. (2005). The stages of new political regimes: the transformation of capital cities. European Review, 13(1), 33-45. Retrieved from https://hdl.handle.net/1887/2864

Version: $\quad$ Not Applicable (or Unknown)

License: $\quad$ Leiden University Non-exclusive license

Downloaded from: $\quad$ https://hdl.handle.net/1887/2864

Note: To cite this publication please use the final published version (if applicable). 


\title{
The stages of new political regimes: the transformation of capital cities
}

\author{
W I M B LOCKMANS
}

NIAS, Meyboomldan 1, NL 2242 PR Wassenaar, The Nethellands

E-mailw p blockmans@let leidenunıv nl

Cities, and especially capital cities, have always ofteied a stage for political ceremonies, testivals, processions, triumphs and stiuggles The built mass in the centre, the axial streets and the accesses of capital cities consisting for a considerable pat of public buildings and open spaces which have piactical and symbolic functions for the state By their shape, location and decoration, the buildings express the vision of political power as the rulers wanted it to be disseminated This paper focuses on the changes introduced in existing cityscapes by rulers representing new ideologies, especially in Istanbul, Moscow and Berlın

In his overview of the architectuial history of European cities, Leonardo Benevolo showed how deep the influence of monarchical power has been in reshaping the urban moiphology in the early modern times States had become more powerful and their 1uleis wanted to show off their newly acquired position Huge buildings had to stress the significance of the seats of government as well as the symbolic places ${ }^{1}$ The focus in this paper is on the reconstructions in capital cities when these had come under an ideologically different regime How did the new masters expiess the nor elty of theit political aims within the existing cityscape? Which models were thought to be distinctive vis-à-vis the previous regime?

The Fiench revolutionaries who formulated in 1789 the Declaration des droits de l'homne et du citoyen, wanted their ideals to be applicable to all inhabitants of the now state Equality before the law would, for the first time in European history, be applicable in the whole territory of the monarchy In contiast to the Roman Empire, crizenship in the Ancien Regime had generally not been extended beyond the walls of the cities or local communities The burghers were so jealous of keeping then privileges restricted to themselves, and they exploited the countrymen so obviously, that they farled to create some kind of loyalty to larger political units than those they could dominate directly This resulted in constant 
particularistic rivaliy and, in the end, to the subordination of most European citıes to dynastic states Nevertheless, the ideas of freedom and civic society remained very much embedded in the urban societies, where they had emerged since the tenth century Therefore, Lafayette and Siéyes could not imagıne any other term to designate the individual enjoying full rights than citoyen, which evidently referred to the privileged inhabitant of a city Other terms such as bugher, bourgeotste, citızenship, code ctvil all refer to their urban origin Nationhood became a common denominator only about a century later, and proved to be a lot more controversial, or, more precisely, just as controversial as the local identifications, but more dangerous because 11 was so much larger and mightier

Evidently, this implies much more than terminology The Geiman legal historian, Gerhard Dilcher described the pre industrial urban civic society as the hothouse where the conceptualization of citizenshıp within the framework of states could be developed ${ }^{2}$ Not only did modern ideology find its roots in the cities, these also were the basis of military power Since the demise of fortresses bult by the feudal lords, that took place, depending on the region, from the 12 th century onwards, cities were the real seats of power In order to get control over a region, one had to besiege and garrison its towns Their location was chosen for strategic convenience, and as concentrations of capital they had become even more strategic Since the 1540s, the kings of France had constructed a series of fortifications along their fiontier with the Habsbuig Low Countries and a similar effort was made on the other side of the border Under King Louis XIV, especially after the Treaty of Utrecht in 1713, all French borders weie piotected by the systematic construction of fortifications by Vauban and by garrisoning these cities Those garrison citıes then became reduced to their function for the defence of the state's territory The social revolutions, which did change the world, took place in the cities and were successful in those situations where the bouigeoisie and the urban proletal 1 at were able to mobilize a strategic weight of the resources

Could the nation states, which grew so strongly during the 19th century, replace the cities as the main focus for the orientation of political values? A preliminary, maybe trivid but fundamental, observation has to be made when one tries to evaluate the social reality of cities and states A city offers a daly material context in which an overwhelming majority of the inhabitants of indusirial states are living A city plan, even that of the larger ones, normally belongs to the mental maps people have in theil memory It has always been possible to know a city by personal and physical experıence, by having walked or been driven through it and to have experienced the distances Urban dwellers normally know the character of strects and quarters, the style of the buildings, the particular social composition, sometimes even the smell All this can be observed and experienced by everybody's senses, it is material, visible, real On the other hand, states need their decision-making to take place within a fairly close ared in which people can 
meet frequently and rapidly. In other words, states have to operate from a basis of city-centres, for their own efficacy. But their conspicuous presence in the capital also provides them an essential means to manifest their position and their purposes, to make this clearly visible to the public eye.

What is a state in the experience of its citizens? Before the great revolutions, the monarchy has certainly been the main common identity element for the subjects of a state. Most states incorporated various nations and this level of identification, just as the sense of belonging to a local community must have remained for a long time stronger than that of the state. After eliminating the monarchy, the French Jacobins felt the need for new emblems, symbols and ceremonies, and made great efforts to create a new sense of nationhood. ${ }^{3}$ The levée en masse helped to forge it in a few years, and indeed neither the Restoration of the monarchy nor the two Imperial periods dared to eradicate those symbols. But, notwithstanding the rallying power of images such as Marianne, the tricolore, the slogan liberté, égalité, fraternité or the Marseillaise, the state remained distant and notably abstract. Nobody could know the state and all its institutions, nor, more precisely, its entire population and territory, as one could know a city. The physical experience any individual may have of a country is, by its sheer dimensions, necessarily less encompassing and less frequent. Therefore, the mythical concept of the nation was propagated as the personification of the common soul of all the citizens. Again, the terminology points to the difficulty in identifying oneself with a state, which is an organization with which the territory did not coincide, certainly not during the 19th century, and very often not during the 20th either, with the emotionally embedded concepts of the traditional territory and community, or even of the nation. It should be clear that states did have an interest in confusing and strengthening these concepts, suggesting the unity of territory, state and nation. Evidently, during the 19th century state-makers tried very hard to make people believe that state, nation and country were overlapping concepts, and nationalist movements scored not negligible impacts in this field, albeit often in mutual conflict. However, as we all know, the last four decades made it clear that the older identities remained strong enough to reappear in new shapes in many regions. The revolutionary movements which broke up the Soviet empire were urban, and they showed the continued effectiveness of the concept of civic society, notwithstanding the tendency towards individualization fostered especially by the modern media.

States are remote and abstract, and their means of identification unavoidably ran into a competition with the centuries-old sense of belonging to a locality, a church, or a national entity. As an organization, the state of the 19th century had primarily administrative links with its citizens, felt at border controls, by taxation, and by jurisdiction. The remoteness of officials performing these and other tasks did not help to provide a more realistic, concrete and material appearance to states. 
Its most effective presence was, as during the Revolutionary and Napoleonic wars, compulsory military service, and indeed repeated warfare. As Eugene Weber has shown for France, the regional mixing of recruits and their subordination to the dominant language, targets, symbols and rituals of the state, was very effective in forging a national feeling coinciding with its entire territory. From around 1900 onwards, secularization of compulsory education also made the state visible in every locality through its schools, and by imposing a teaching programme in the minds of entire new generations. Children could now be taught that they were born to belong to a great nation which history proved had always been there, gloriously and beneficially. ${ }^{4}$ The Great War was just as much a consequence of exacerbated nationalism, and strangely enough, its continued fosterer. The cult of war victims kept these feelings alive, monuments and ceremonies made them present even in the tiniest village.

State-makers have tried for centuries to impose themselves on the urban populations by other means, namely by using public space as a theatre to express their own messages. In urbanized societies, cities have always been the theatres par excellence for the powers to show off. The city walls evidently were the very first expression of the particular status of urban communities in medieval and early modern Europe. They belong to the first large investments made by the community as a whole, leading to the creation of public finance and of the concept of common weal or 'bonum commune'. Their gates were articulated in the architecture as the places where entering and leaving had far-reaching juridical, financial and social effects. A lord, bishop or prince entering a city was always welcomed by the local authorities outside the gates, and his passage through a gate was accompanied by symbolical acts - such as the offering of the keys - to mark the transition into a particular space. ${ }^{5}$ City gates were closed at night and in periods of political tension. In times of dearth, poor from the countryside were kept out, to restrict almsgiving to the citizens only. Gates thus were the focal points where the distinction was made physically between the privileged inhabitants and the outside world. It was a common sanction to ban delinquents from the city, which made entry control necessary. Similarly, goods brought into a city or exported from it had to be checked for their provenience, quality and taxation. In the 1780s, King Louis XVI had 45 gates built around Paris as toll stations. His architect Claude-Nicolas Ledoux created at each of these barrières impressive neoclassical monuments. As late as 1825, the city-sate of Bremen constructed similar toll gates.

Within a city, private and public buildings expressed the ambition of families and institutions. The elevated fortress of a lord might be challenged by the height of the bell tower of a church or a city hall. Cathedrals were erected with the funds of the local community as the principal expression of their faith, devotion, world-view and self-confidence. Patricians built their private fortified houses and these not seldom had a tower, which was as much an intimation of noble privilege 
expressing high status as well as a very practical infrastructure in the frequent armed conflicts between rivalling sections of the urban elites. The types of buildings prominent in a particular city and their location in relation to each other and to the public space as a whole can be considered as the main signifiers of the identity of an urban community and its constituent parts. This observation makes it possible to decode European history through the architectural and morphological symbols imposed upon the cities by competing powers. Only a few examples can be mentioned here, which demonstrate possibilities for a closer collaboration between specialists in the history of architecture and the visual arts with urban historians, in order to understand better the symbolism of urban morphology.

Since they counted so many more inhabitants, cities, and especially capital cities, have always offered the stage for political ceremonies, festivals, processions, triumphs and struggles. The built mass in the centre of capital cities consisted of a considerable part of public buildings and open spaces, which had practical and symbolic functions for the state. By their shape, location and decoration, the buildings expressed the vision on political power as the rulers wanted it to be noted. Some buildings, such as a cathedral or palace could fulfil their symbolic and legitimizing functions for different political regimes, with only minor adaptations of the ritual. In that sense, the continuity of the exercise of power was sustained by the re-utilization of the traditional monuments. In some cases, however, the political change so deeply involved the ideological and religious foundations of a regime, that it felt the need to destroy old symbols and build entirely new ones. A noticeable example of this is the demolishing and reconstruction since the mid-1990s of the cathedral of Christ the Saviour in Moscow.

Buildings, roads and spaces were used for public ceremonies, such as the triumphs in ancient Rome, or the advent of a new bishop in his city. Entering a city, kings and princes were welcorned outside the gate. The city offered the stage where the rituals of power could be performed before the masses considered representative of the entire population of the state. The sinister Auto da Fé of the Spanish crown and Inquisition were staged on the Plaza Mayor in Madrid; these squares were by themselves typical representations of royal power in Castilian cities, constructed systematically through the country from the 17 th century onwards. There were also rites de passage such as the yearly inauguration ritual of the Lord Mayor of London followed by a progress through the city, first by barge along the Thames, then from the Guildhall to Westminster Palace, where an oath was taken. Back in the commercial city, a pageant was normally performed in St. Paul's churchyard. ${ }^{6}$ All these performances were shown and explained in prints for the wider public, which had been unable to attend to see and understand everything. 


\section{New Rulers, New Cityscape}

The question to be discussed more precisely now will be how did new rulers, representıng a different ideology and a new political system, use, adapt or even reshape the urban morphology of capital cities? The creation ex nihllo of a new capital city for a new state, as occurred in the case of Berlin from Elector Fiederic William I in the middle of the 17 th century, or even clearcr in that of Helsink 1 in 1818-1828, is rather exceptional Transfer of the residence of the same regime to another place, such as that of the Polısh kings tiom Cracow to Warsaw or the Spanish from Toledo or Valladolid to Madrid in the 16th century may well reflect the adaptation to a larger territory and a more centralistic view on the state This remained, however, a giadual development within the same ideological context Matters became different when a truly revolutionary discontınuity occurred in the political as well as in the cultural sphere The brutal implantation of a Catholic church in the Great Mosque of Cordoba under Empero1 Charles V, or the construction of his Palace in the Alhambra in Granada in the 1520s are striking cases of the ddaptatıon and re-use of established seats of a subordınated power

In Strasbourg, a completely new imperial quarter was constructed outside the medieval city in the years 1871-1914 This offers a more recent case of the implantation of a culturally and religiously different dominant state in a city After its victory over France, the newly created German empire wanted to show off its power, especially in this frontier city which had belonged to the Empire during most of its history and where the local population stıll spoke a German dialect The second Empire now approprated this symbolic space in order to reorient the subjects In a geometric design, an imperial palace, a library, a thedtre, the university and administratıve buldings obviously were meant to demonstrate the superionty of German culture Huge statues of great men decorated the university building

The transfer of capital cities back to locations which had already been the capital of a previous regime, such as Moscow and Berlin, shows in this respect the same problems as the tiansformation of a continuous capital such as Paris or Rome The Kremlin complex thus offers an exceptiond catalogue of the adaptations and extensions of a kind of Holy City where successive regimes edch created theil own niche in the immediate vicinity of their predecessors' monumental symbols The traditional symbolic capital could thus be incorporated in a new legitimacy Generally, it proved far more advantageous to continue to exploit existing locatıons, adapting them to a new visible ideology Munich is another stuking case After the 1848 revolution, the old Bavarian capital was endowed with a Kontglicher Platz, a toyal squate surrounded by an imitation of the Akropolis in Athens, including a Propylaea gate and an ensemble of museum and academic buildings in neoclassical style New axes were designed in the uban morphology 
and new architectural styles were developed. So, the Ludwigstrasse was created in a neo-Florentine style. The Bavarian monarchy, raised to royal rank in 1805 , wanted to show off vis-à-vis the competing capitals Vienna and Berlin. Interestingly, this ensemble was supplemented under Nazi rule with two temples of Honour, a Führerbau and, further away, by a museum. These examples suggest an interest in focusing on the question of which features in the morphology of capital cities have been changed by new authorities, and for which purposes.

A survey of some striking cases in European history can help us to understand the symbolic function of urban morphology, not only for the interest of the city dwellers, but also for that of all inhabitants of the state. The administrative centre of Paris was transformed not merely through the names and functions of existing buildings and squares, such as the Palais de Luxembourg and the Palais Bourbon becoming the Parliament buildings, and the Place de la Liberté into Concorde, but by reshaping the global urban texture into a coherent and transparent structure. Hausmann's Paris reflected the clarity of the centralistic state structure, as well as its profoundly bourgeois character, at least in the capital. The reconstruction of the Ring in Vienna in the 1870 s and 1880 s reflected a similar ambition, albeit with a markedly imperial overtone. ${ }^{7}$ In both cases, the needs to rebuild the infrastructure of a rapidly growing industrial metropolis were taken as an opportunity to express the newly won self-confidence of the bourgeoisie. They imitated former exclusively courtly behaviour by having built for themselves, a house of parliament, governmental buildings, a university, theatres and museums, all decorated with a magnificence which could compete with that of their imperial rulers or predecessors.

\section{Constantinople, Byzantium and Istanbul}

Constantinople certainly was the most dramatic case of a European capital city being adapted in a short time to a central role in a very different type of state disseminating a different religion, culture and ideology. Its three successive names already suggest its functions in, successively, the Roman, the Byzantine and the Ottoman empires. The transition from the Roman to the Byzantine capital may have been gradual and unnoticed by contemporaries, since the loss of Rome's central role did not become clear at any one particular moment. By contrast, the break after the siege and occupation by the Ottoman Turks in 1453 was very deep and sudden. The expansion of the Ottoman Empire had taken place initially in Asia. During the 14th century, parts of the Balkans were occupied, in 1512 Syria and in 1520 Egypt were added. Ethnically, Turkish peoples became dominant, and hence culturally the Arabic language, Islam and its way of life. All this was accentuated by the displacement of large segments of the urban population and massive compulsory settlements of Turks. The capital city had to be repopulated 
after Byzantium's long decay. In the $1480 \mathrm{~s}$, the population had risen to an estimated maximum of 85,000, of whom 58\% were Turkish, 23\% Greek and 19\% of various other Christian and Jewish origins. What changed in the urban architecture when Byzantium became Istanbul, the centre of an Islamic empire?

We can distinguish between the measures taken immediately after the conquest and later changes. First, the fortifications dating from Justinian's time were preserved, although they had proven their inadequacy against gunfire. Next, large sections of the city's territory were granted to the Hagia Sofia, which was soon converted into a mosque. Similarly, many smaller churches and cloisters were similarly reshaped into mosques, and new mosques were built in the new Turkish settlements. In 1457 the construction of the Eski Saray palace started with its high walls on the location of the antique Forum Tauri, which previously had been a lively open square. In 1455-61, the old economic centre was converted into a fortified great Bedestan surrounded by the Bazar, with the shops of the jewellers and goldsmiths and the first Hamman. Within the first ten years after the occupation, the waterworks were swiftly renovated in large sections of the city. Water towers, distribution basins, fountains and baths were erected. These constructions were related to urgent practical needs triggered by the huge immigration after the period of decay. ${ }^{8}$

The most important symbolic project of the first years concerned the Church of the Apostles, where Constantine had been buried. There, in 1463-70, the new rulers constructed a complex comprising the Fatih Mosque, surrounded by eight large and eight smaller medresseh, Koran schools, and a number of other pious foundations such as hospitals. These complexes of buildings belonged to an institutional setting typical for the Islamic world. It was therefore most significant that the most essential locations for the Christian identification of the city, Constantine's Hagia Sofia and his burial place, were converted into the main foci of the new worship within ten years after the conquest. Not only the Sultan but also his Viziers founded mosques with the baths and schools belonging to the cult. These complexes became the centres of the new urban quarters, where the new lifestyle was propagated. In the same period, 1465 to 1470, the Sultan started the building of the Yeni Saray, the present Topkapi Saray, surrounded by strong walls isolating the palace complex from the city.

In Pera, on the other bank of the Golden Horn, Italian and especially Genoese merchants received confirmation of most of their privileges, although they had to pull down parts of their fortifications. So, during the first 20 years of Turkish rule, the demolition of the old market square, the conversion or demolition of the two main Christian churches, the construction of two new palaces, the Bazar and a series of mosque complexes including Koran schools, libraries and baths, brought rapid and thorough change to the public space. These adaptations responded to the specific needs of the capital city of an Islamic state. Strangely 
enough, the Hagia Sofia was not only treated with respect, it even became the model for mosques throughout the Ottoman Empire. Even this Empire, which took great care to restructure the public space swiftly and profoundly, had thus derived the most essential features of its new symbolism from the venerated previous regime. Renovation still needed a touch of antiquity to seem entirely convincing. In that respect, the architectural design of its mosques remained distinct from that in the Muslim countries in the Western Mediterranean.

After the conquest of Syria and Egypt, Constantinople became the seat of the Caliphate, and thus the metropolis of the whole Islamic world. The 16th century was a period of strong population growth and territorial expansion. Under Sultan Suleyman the Magnificent, 1520-1566, and his immediate followers, a whole series of very large mosque complexes was built on the initiative of the sultan, his family and viziers. They all followed the model of the Hagia Sofia, with huge cupolas and slender minarets which gave the city its typical silhouette, still evident today; most prominent was the Suleymanyi mosque, built in 1543-48. This entire building programme included seven large complexes situated on seven hills of the city, which was another imitation of a classical model, that of ancient Rome. It was important that the names of the founders of the mosques were known to the public as general benefactors. The sultans and their relatives required that they were to be buried in mosques of their own foundation which were evidently dedicated to worship, but also had important social functions such as providing food for the poor (imarets). Around 1600, the Islamic metropolis contained some 120 medresseh and 86 hospitals. Islam prescribed war against ignorance just as it prescribed relief for the poor and the sick. The city had become the material expression of these priorities, constructed under the auspices of the new elite. It was their heavenly mission to launch building programmes that entirely transformed the urban environment. After 1600, construction activities slowed down and did not change much from the pattern preserved until the present day.

\section{Moscow}

For Orthodox Christianity as the successor of Byzantium, Moscow equally offers an interesting case in which the fundamental political change of the Communist revolution was made visible. On the one hand, the renewed function of the Kremlin fcrtress as the seat of central power marked the desire for recognition and the search for legitimacy through the appearance of continuity. It was only in the 1960s that the People's Palace added a touch of modernity to the prestigious buildings from previous centuries. The more fundamental interventions of the Stalinist regime were evident in an urban morphology linking this capital city again with ancient Rome. In the 1940s and 1950s, skyscrapers were implanted on seven hills around the city and the university buildings moreover offered a 
panoramic view on the city as a whole ${ }^{9}$ These buldings were in the neo-Florentine style which had been popular in New York some 60 years before The first grandiose construction piogramme of the Stahnist regime had been the metro system, started in times of severe hardshrp during the 1930s but nevertheless was endowed with a conspicuous iconographic programme executed in very expensive materials This huge investment was thought to be an effective means of popular1/1ng the new ideology among the masses In the 1970s, television towers became the new symbols of the allegedly technically ddvanced state power, in Moscow and elsewhere The fire drama in the Moscow television tower in 2000 made it very clear how much this technically daring construction was felt to be symbolic for the greatness of the state (The ideological dimension of tower buldings became clearer than ever after the 11 September 2001 attack in New York, whose Twin Towers wete seen by its aggressors as the symbols par excellence of Western capitalism and materialısm ) In the post-communist era these phenomend are embodied in Moscow in the now exclusive GUM gallery on the Red Square, which is a renovated building from the Tsarist era The symbolism could hardly be more pregnant, the happy few of the present regime can buy their Western exclusivities right in front of Lenin's mausoleum, on the most symbolic square of Communism, in a bulding dating from the pievious autocracy Obviously, the present state makes it very clear how far it keeps its distance from the ided of the State being the main economic actor No doubt there will be other instances, notably by private companies that will determine the new morphology of the capital city

\section{Berlin}

Berlin certainly will be the most complex and controversial case in this brief survey Five successive political regimes have supeiposed their marks, including luins, in its uban morphology In the euphorid dfter Napoleon's defeat, a vast restructuring of the monumental centre was launched In the 1820s, the bat oque city palace of the Kings of Prussid became one of the focal points in a global design by the architect Schinkel ${ }^{10}$ He connected the castle and its gardens with a bioad place over the 1sland, in fiont of the Neue Wache (new guard's housc) at the beginning of the Unter den Linden A wide bridge decorated with sculptures formed a new symbolic city centre, including the Zeughaus (Arsenal), the Cathedral, Prince Albert's palace, the old museum and, at the very end of Unter den Linden, the Brandenburg gate In the Imper lal period, the university, the opera and the Reichstag buldings were added From 1822 onwalds, statues were erected here of five generals, among whom were Bulow and Blucher They were removed in 1948 together with Fredenc the Great's equestı ian statue in the middle of the 
square; three were re-installed in the garden besides the Opern Café. Frederic got his central position back in 1981 .

The Nazi regime developed some of these zones further with such constructions as the Ministry of the Air Force. This building fulfilled functions under all the successive regimes, finally as the Treuhand which restructured the GDR-industries after the removal of the Wall. Most remarkable in the Nazi regime were the global urban plans designed by Albert Speer in 1942 which were intended to create a new and grandiose urban centre, of which the Tempelhof airport is a well-preserved remnant. North and South railway stations were incorporated in the plan with the Siegesallee, the Lane of Victory, as its main axis. Its focal points were to be a Triumphal Gate, $117 \mathrm{~m}$ high and $170 \mathrm{~m}$ wide and a Great Hall for 150,000 persons with a $290 \mathrm{~m}$ high cupola. Interestingly, this gigantic building, with a base of 315 metres, was to be constructed on the Königsplatz, to replace the main symbol of an older regime. ${ }^{11}$ The GDR authorities shared the desire to express their ideology by the demolition of that city palace of the Prussian kings in 1953. They renamed the place after the Republic and put up instead a Palace of the Republic, open for the general public and as a meeting place for the People's Congress. The adjacent emply space received the name Marx-Engels-Platz and was intended for public announcements and demonstrations. These remnants of the past were intentionally destroyed with the construction of the grandiose Karl-Marx-Allee, and basic housing on Fischer island and in the suburbs.

The re-united Federal Republic in its turn launched a gigantic building programme in which private initiatives were to create an entirely new and lively city centre on the Potsdamer Platz. The local government left the task of reshaping the city centre to multinational private companies, albeit under the critical control of public debate in the Stadtforums. Siemens acted as a city developer, Daimler-Chrysler turned into real estate developers targeting the well-to-do bourgeoisie, all under the strict regulations of the city government. Shops, theatres and restaurants showed the attractions of the consumer society in a splendid new architectural style. The experience of totalitarian states re-building cities in their own image had led to a near-complete withdrawal of the public initiative. It seems as if we are back in the situation where the city is re-shaped not by clergymen, noblemen, or state officials but by the burghers. The new challenge seems to be how to reconcile the miechanisms of the global economy with the need of citizens to live in a community with which they can identify and can feel a sense of belonging. ${ }^{12}$

\section{Conclusions}

This comparison of the transformations occurring in the morphology of some capital cities as a consequence of the revolutionary changes in states leads us to 
a number of conclusions First, we observed the repedted endeavour of new state regimes to transform the urban morphology in order to provide an adequate expression of their ideology Particular types of buldings with specific functions had to be constructed, transformed or demolished The urban architecture needed to be imposing, visible, omnipresent and easy to undeistand Associations with older models helped to provide legitimacy to new regimes

Second, the city remaned the place where socrety becomes a tangıble ieality, thanks to its large scale and the density of its direct social interactions Notwithstanding the strong tendency towards individualization thiough the media, the city continued to respond to a need for a material scenery, whose context of meaning attracts people to a lively centre rather than to the megastores of the suburbs

Third, at the end of the 20th century, the state's position appears still very prominent in the capital cities, even if they show a tendency to withdraw and leave the initiative largely to private companies This has been discussed in the case of Berlin, but the dockland reconstructions in London and Oslo confirm this tendency The growing supranational authority of the European Union is markedly present only in one Brussels quarter, and on a much lesser scale in complexes in the outskirts of Luxembourg and Strasbourg The lack of clarity of its image is reflected in the diversity of its architectural styles in buildings mostly designed for various purposes

Fourth, symbolic buldings still bring about lively discussion and emotional reactions linked to the sense of belonging, as was demonstrated at the occasion of the fire in the Moscow television tower and the debate about the reconstruction of the Berlin city palace

Fifth, the decreasing influence of public authorities compared with the high visibility of multinational companies with their conspicuous skyscrapers rases the question of the great financial power of private capital to invest and reconstruct whole urban quarters Will this new emphasis find a way to respond to the need of the inhabitants to identify with a particular urban structure relating to their historical, cultural, and local roots?

\section{References}

1 L Benevolo (1993) La citta europea (Rome Later/a), chapter 5 (avallable in several translations)

2 G Dilcher (1996) Burgerrecht und Stadtverfassung im europalschen Mittelalter (Cologne/Weimar/Vienna Bohlau) 358-361, G Dilcher (1997) The issue city and state In P Blıckle (Ed), Resistance, Representation and the Sense of Communtty (Oxford Cldrendon Press) 291-300 
3. M. Ozouf (1976) La fête révolutionnaire, 1789-1799 (Paris: Gallimard); A. Corbin, N. Gérôme and D. Tartakowsky (Eds) (1994) Les usages politiques des fêtes aux XIXe-XXe siècles (Paris: Publications de la Sorbonne).

4. E. Weber (1976) Peasants into Frenchmen. The Modernization of Rural France 1870-1914 (Stanford).

5. G. Kipling (1998) Enter the King: Theatre, Liturgy and Ritual in the Medieval Civic Triumph (Oxford: Clarendon Press).

6. D. Cressy (1989) Bonfires and Bells. National Memory and the Protestant Calendar in Elizabethan and Stuart England (London: Weidenfeld and Nicolson).

7. See the article, in this issue, by Herman van der Wusten.

8. A. Batur (Ed) (1996) Istanbul World City. Exhibition Catalogue (Istanbul: The Economic and Social History Foundation of Turkey).

9. K. Burton (1977) Moscow, an Architectural History

10. H. G. Pundt (1972) Schinkel's Berlin, A Study in Environmental Planning (Cambridge, MA: Harvard University Press).

11. M. Burleigh and W. Wippermann (1991) The Racial State: Germany 1933-1945 (Cambridge: Cambridge University Press).

12. B. Flierl (1998) Berlin baut um - Wessen Stadt wird die Stadt? (Berlin: Verlag für Bauwesen); G. Zohlen (Ed) (1999) Berlin: offene Stadt. Vol. 1: Die Stadt als Ausstellung. Vol. 2: Die Erneuerung seit 1989 (Berlin: Nicolai).

\section{About the Author}

Wim P. Blockmans is Rector of the Netherlands Institute for Advanced Study and Professor of medieval history at Leiden University. His research interests include the development of cities and their relation to state formation in late medieval and early modern Europe. He was co-editor of Origins of the Modern State in Europe, 13th to 18th Century, 7 vols (Oxford: Clarendon Press, 1995-98); Cities and the Rise of States in Europe, A.D. 1000-1800 (Boulder: Westview, 1994) and is the author of A History of Power in Europe: Peoples, States, Markets (Antwerp: Mercatorfonds, 1997); Emperor Charles V 1500-1558 (London: Arnold, 2002). 